\title{
Persepsi Ibu, Dukungan Suami dan Dukungan Tempat Kerja dengan Pemberian Asi Ekslusif pada Ibu Bekerja di CV X
}

\author{
Erika Srirahayu Ningsih ${ }^{1}$, Retno Sugesti ${ }^{2}$, Milka Anggreni Karubuy ${ }^{3}$ \\ ${ }^{1,2,3}$ Program Studi Kebidanan Program Sarjana Terapan \\ Sekolah Tinggi Ilmu Kesehatan Indonesia Maju \\ Jln. Harapan No. 50, Lenteng Agung, Jakarta Selatan - Indonesia \\ Email: ${ }^{1}$ rika@gmail.com, ${ }^{2}$ retnosugesti.stikim@gmail.com, \\ ${ }^{3}$ milkaanggrainikarubuy@gmail.com
}

Editor: H, Nina

Hak Cipta:

(C)2021 Artikel ini memiliki akses terbuka dan dapat didistribusikan berdasarkan ketentuan Lisensi Atribusi Creative Commons, yang memungkinkan penggunaan, distribusi, dan reproduksi yang tidak dibatasi dalam media apa pun, asalkan nama penulis dan sumber asli disertakan. Karya ini dilisensikan di bawah Lisensi Creative Commons Attribution Share Alike 4.0 Internasional.

\section{A B S T R A C T}

Introduction: Failure, The success of exclusive breastfeeding is due to the working mother.The failure factor to exclusively offer breastfeeding to working mothers is due to working mothers and the unavailability of breastfeeding room facilities and lack of support from the workplace.

Objectives: The research objective was to determine the mother's perception, husband's support and workplace support by giving exclusive breastfeeding to working mothers at CV. Tri Corp Bogor Regency in 2019.

Method: The research design used was a cross sectional study. The population in this study were mothers who worked at CV. Tri Corp Bogor Regency as many as 42 people. The sample used was 43 respondents with the sampling technique with the total sampling method. Data analysis using Chi Square test.

Result: Based on the results of the investigation, it was found that 22 people were given exclusive breastfeeding (53.4\%), 22 people had poor perceptions of mothers (53.4\%), 23 people (54.8\%) had poor support, local support good work as many as 24 people (57.1\%). The statistical test results of the relationship between maternal perceptions and exclusive breastfeeding with a $P$ value $=0.014$. The relationship between partner support and exclusive breastfeeding with a $P$ value $=0.032$. The relationship between workplace support of exclusive breastfeeding with a $P$ value $=0.011$.

Conclution: The conclusion is that there is a relationship between maternal perceptions, workplace support and support by providing exclusive breastfeeding for mothers working at CV. Tri Corp Bogor Regency in 2019. Suggestions for research sites to be able to provide health workers for pregnant and breastfeeding mothers as well as increase breastfeeding space and provide exclusive breastfeeding policies for mothers with children 0-6 months.

Keyword: perception, husband support, mother's worker, breast milk. 


\section{SIMFISIS Jurnal Kebidanan Indonesia}

Volume 01, Nomor 01, Agustus 2021

\section{Pendahuluan}

Air Susu Ibu (ASI) ialah makanan bayi yang terbaik yang diberikan dari tuhan sehingga tidak bisa ditiru oleh ahli makanan dari manapun. ASI ialah nutrisi alamiah yang baik untuk bayi yang mengandung berbagai macam energi serta zat yang dibutuhkan pada selama enam 6 sejal lahir bagi kehidupan bayinya. Pemberian ASI di Indonesia harus perlu ditingkatkan serta dibudayakan untuk bisa diberikan secara eksklusif. ASI eksklusif ialah ASI yang diberikan untuk 6 bulan pertama tanpa diberikan tambahan yang lain diantaranya susu formula, madu, jeruk, air putih maupun air teh, serta tidak diberikan makanan tambahan padat seperti bubur, buah pisang, bubur nasi, biscuit serta nasi tim. ${ }^{1}$

Sustainable Development Goals dalam The 2030 Agenda For Sustainable Development mentargetkan di tahun 2030 dapat mengurangi angka kematian anak sedikitnya 12/1.000 kelahiran hidup serta kematian anak usianya $<5$ tahun sedikitnya 25/1.000 kelahiran hidup. Hal itu akan tercapat jika diberikan ASI eksklusif diterapkan dengan baik. Namun, data dunia hanya 44 persen dari yang bayi baru lahir mendapat ASI dalam waktu 1 jam pertama sejak lahirannya, bahkan bayi usia di kurang enam bulan hanya sedikit yang diberikan eksklusif. Diberbagai negar cakupan pemberian ASI eksklusif yaitu diantaranya Amerika Latin dan Karibia sebesar 32\%, Afrika Tengah sebesar 25\%, Asia Timur sebesar $30 \%$, serta Asia Selatan sebesar 47\%, negara berkembang sebesar $46 \%$. Dengan keseluruhan data tersebut jika dirata ratakan tidak kurang dari $40 \%$ bayi $<6$ bulan yang diberi ASI Eksklusif. Hasil itu belum sesuai pada target WHO yaitu sedikitnya 50\% anak diberikan ASI ekslusif. ${ }^{2}$

Data dari Kemenkes Indonesia diketahui cakupan ASI eksklusif yaitu sebanyak 29,5\%. Hal itu belum sesuai pada target yaitu sebesar 50\%. Di Kabupaten Bogor Pada bayi 0 hingga 6 Cakupan ASI eksklusif sebanyak 53,8\% masih tinggi dari pada cakupan nasional. Kebutuhan bayi akan zat gizi di awal kehidupan sangat kecil apabila dibandingkan pada orang dewasa. Namun dapat berbeda jika kebutuhan tersebut perbandingan dengan persentase berat badannya. Hasilnya kebutuhan zat gizi bayi dapat melebihi kebutuhan orang dewasa serta dapat mencapai 2 kali lipatnya. ${ }^{3}$ ASI ialah yang paling baik untuk bayi dikarenakan kandungan zat gizinya lengkap serta sesuai kebutuhan bayinya. Komposisi ASI unik karena dapat berbeda pada ibu yang satu dengan ibu lainnya. Selain mengandung berbagai gizi yang dikebutuhan oleh bayi, ASI terkandung berbagai enzim-enzim yang akan membantu bayi dapat mencerna zat-zat gizi tersebut sehingga ASI dapat menjadi mudah untuk dicerna. Dampak dari tidak diberikannya ASI secara eksklusif ialah selain dapat menyebabkan kematian bayinya yaitu adanya kerentangan pada kesakitan bayi. ASI dapat melakukan penceganan dari kejadian diare serta ISPA pada bayi serta penyakit pada usus. ${ }^{4}$

Dalam rangka angka penurunan kesakitan serta kematian bayi, berdasarkan UNICEF dan WHO bahwa sebaiknya bayi hanya cukup diberikannya ASI, serta dapat dilanjutkan selama usianya sampai 2 tahun untuk ibu dapat memberikannya ASI kepada bayi secara eksklusif untuk itu WHO merekomendasikan agar dapat dilakukan IMD sejak 1 jam kelahiran anaknya, bayi hanya mengkonsumsiASI tanpa adanya makanan tambahan ataupun minuman, termasuk air, menyusui sesuai permintaan, tidak dianjurkan dengan botol atau dot. UNICEF bersama dengan World Health Assembly (WHA) serta banyak negara lainnya akan merekomendasikan ASI secara eksklusif karena dapat memberikan efek positif bagi ketahanan hidup bayinya. Pemberikan ASI eksklusif akan menunjang daripada kecerdasan bayi, namun memang tidak mudah untuk dilakukannya. ${ }^{5}$

Kegagalan diberikan ASI terdiri dari beberapa faktor diantaranya ialah faktor internal; pendidikan, pengetahuan, sikap/ perilaku, psikologis, estetika, tekanan batin, fisik ibu dan emosional, faktor eksternal; peranan ayah, sosial serta budaya, ibu yang bekerja, petugas kesehatan, peningkatan promosi susu kaleng pengganti asi, informasi yang diterina salah, tidak IMD dan faktor penyakit ibu. ${ }^{6}$ 


\section{SIMFISIS Jurnal Kebidanan Indonesia}

Volume 01, Nomor 01, Agustus 2021

Kenaikan partisipasi ibu yang bekerja dapat menurunkan persediaan menyusui serta lamanya menyusui. Berdasarkan data BPS tahun 2013 dalam kebijakan Depkes tentang peningkatan pemberian ASI pekerja wanita. Waktu cuti hanya 3 bulan memaksa ibu untuk dapat memulai kembali bekerja walaupun bayinya masih membutuhkan ASI. Persepsi ibu bekerja tentang ASI Eksklusif dapat berupa kesan, penafsiran, atau penilaian berdasarkan pengalaman yang diperoleh, dimana persepsi merupakan suatu proses pengambilan keputusan tentang pemahaman orang dalam hal ini ibu bekerja dikaitkan dengan suatu obyek / ASI Eksklusif. ${ }^{7}$

Berdasarkan hasil penelitian yang telah dilakukan sebelumnya, menyebutkan bahwa banyak alasan yang menjadi penyebab seorang ibu tidak memberikan ASI eksklusif kepada bayinya. Hasil penelitian oleh Helda bahwa menyebutkan bahwa kebijakan tentang hak cuti melahirkan yang diterima ibu bekerja tidak sesuai dengan kebutuhan pemberian ASI eksklusif. Adanya persepsi yang salah bagi ibu tentang menyusui yang mana jika menyusui dapat membuat daya tariknya pada seorang ibu sebagai wanita menurun serta dapat penghambat ASI eksklusif. Alasan lainnya yang rendahnya pemberian ASI Eksklusif ialah kurangnya pengetahuan bagi manajemen laktasi dan sikap terhadap manejemen laktasi. ${ }^{8}$

Dukungan suami sangat berpengaruh terhadap keberhasilan pemberian ASI esklusif. Terdapat dua kategori yang berpengaruh terhadap keberhasilan pemberian ASI ekslusif, salah satu diantaranya ialah pengaruh sosial primer yaitu dukungan orang- orang terdekat. Dukungan suami dapat meningkatkan rasa percaya diri pada ibu menyusui. Produksi ASI juga meningkat karena perasaan nyaman yang dialami oleh ibu yang mendapat dukungan suami. ${ }^{9}$

Berdasarkan hasil penelitian Farha menjelaskan bahwa hubungan dukungan suami dengan kemauan ibu memberikan ASI eksklusif di Puskesmas Tuminting tahun 2014. Hasil uji statistik menggunakan uji chi square didapatkan nilai $\mathrm{p}=0,001$. Ini berarti bahwa nilai $\mathrm{p}<\alpha(0,05)$. Dengan demikian dapat disimpulkan bahwa terdapat hubungan antara dukungan suami dengan kemauan ibu memberikan ASI eksklusif. ${ }^{10}$

Berdasarkan penelitian Rizki bahwa Tujuan penelitian ini ialah untuk mengetahui hubungan sikap, dukungan sarana, atasan dan suami terhadap keberhasilan ibu menyusui pada ibu bekerja. Hasil penelitian didapatkan sikap ibu bekerja, dukungan sarana, atasan dan suami berpengaruh terhadap keberhasilan pemberian asi eksklusif oleh ibu bekerja $(\mathrm{p}<0,05)$. Kesimpulannya ialah ada hubungan yang signifikan antara keberhasilan pemberian asi eksklusif dengan sikap ibu, dukungan sarana, atasan dan suami. ${ }^{11}$

Berdasarkan studi pendahuluan yang telah dilakukan pada tanggal 08 Juni 2019 di CV. Tri Corp kepada 10 (Sembilan) ibu yang bekerja terdapat 4 (empat) orang yang mengetahui tentang ASI eksklusif, dan 6 (lima) orang tidak mengetahui ASI eksklusif, 4 (tiga) orang yang memberikan ASI eksklusif, 6 (enam) orang tidak memberikan ASI eksklusif. Alasan ibu tidak memberikan ASI eksklusif karena bekerja diluar rumah, sering selama ibu bekerja bayi tidak diberikan ASI eksklusif dan digantikan dengan susu formula. Pada ibu yang memberikan ASI eksklusif, 2 (dua) orang sudah mulai memerah ASI tiga minggu sebelum bekerja dan di simpan dalam freezer. Selain menyusui langsung dari payudara ibu, terkadang bayi dilatih di berikan ASI menggunakan sendok agar bayi terbiasa. Sedangkan pada 1 (satu) orang yang memberikan ASI eksklusif, satu bulan sebelum bekerja sudah mulai memerah ASI dan melatih bayi menyusu dengan menggunakan sendok. Ketiga ibu yang memberikan ASI eksklusif sudah mendapatkan informasi bagaimana menghangatkan ASI sebelum di berikan kepada bayi dan cara menghangatkannya. Sebelum berangkat bekerja ibu selalu menyusui bayinya dan juga memerah ASI nya untuk persediaan selama ibu bekerja. Berdasarkan uraian di atas maka penulis tertarik untuk melakukan penelitian tentang Hubungan Persepsi Ibu, Dukungan Suami dan Dukungan Tempat Kerja 


\section{SIMFISIS Jurnal Kebidanan Indonesia}

Volume 01, Nomor 01, Agustus 2021

dengan pemberian ASI Ekslusif Pada Bayi 0-6 Bulan di CV. Tri Corp Kabupaten Bogor Tahun 2019. Tujuan dalam penelitian ini adalah untuk mengetahui hubungan persepsi ibu, dukungan suami dan dukungan tempat kerja dengan pemberian ASI Ekslusif pada ibu bekerja di CV. Tri Corp Kabupaten Bogor Tahun 2019.

\section{Metode}

Penelitian ini ialah jenis kuantitatif yang sifatnya analitik. Penelitian jenis kuantitatif digunakan karena peneliti pengambilan sampel dari satu populasi dengan mpenggunaan kuesioner sebagai alat ukurnya dalam pengumpulan data. ${ }^{12}$ Desain penelitian yang digunakan ialah studi cross sectional atau potong lintang. Desain studi cross sectional digunakan karena dapat memberikan informasi atau gambaran analisis dalam satu waktu yang bersamaan atau dengan kata lain yaitu suatu penelitian untuk mempelajari dinamika kolerasi antara faktor-faktor risiko dengan efek, dengan cara pendekatan, obsevasi atau pengumpulan data sekaligus pada suatu saat (point time approach) ${ }^{13}$ Dalam penelitian ini instrumen penelitian atau alat yang digunakan untuk mengambil data yaitu dengan menggunakan kuesioner atau angket. Kuesioner ialah suatu cara pengumpulan data atau suatu penelitian mengenai suatu masalah menyangkut kepentingan umum atau banyak orang.

Populasi merupakan keseluruhan objek penelitian atau objek yang diteliti tersebut. Populasi dalam penelitian ini ialah ibu yang bekerja di CV. Tri Corp Kabupaten Bogor sebanyak 42 orang. Sampel merupakan objek yang diteliti serta dianggap mewakili seluruh populasi. ${ }^{14}$ Teknik pengambilan sampel dalam penelitian ini dilakukan menggunakan metode Total sampling. Jadi sampel yang dibutuhkan sebanyak 42 responden. Sampel yang diambil ialah karyawan di CV. Tri Corp Kabupaten Bogor Tahun 2019. Semua subjek yang memenuhi kriteria pemilihan dimasukkan ke dalam penelitian sampai jumlah subjek yang diperlukan terpenuhi.

Kriteria inklusi dalam penelitian ini ialah Ibu yang bekerja di CV. Tri Corp Kabupaten Bogor Tahun 2019. Ibu yang selama proses menyusui masih bekerja di CV. Tri Corp Kabupaten Bogor. Ibu yang bekerja di CV. Tri Corp Kabupaten Bogor yang bersedia menjadi responden. Kriteria eksklusi dalam penelitian ini ialah Karyawan Perempuan di CV. Tri Corp Kabupaten Bogor yang belum menikah. Ibu yang bekerja di CV. Tri Corp KabupatenBogor namun tidak ditemui (sesertag sakit atau cuti) pada saat dilakukan pengumpulan data.

Validitas ialah ukuran yang menunjukkan sejauh mana instrumen pengukuran mampu mengukur apa yang ingin diukur. Apabila suatu kuesioner untuk mengukur peran ibu dengan dismenore, maka akan menghasilkan sesuai dengan keyakinan yang dimiliki oleh responden yang diukur. Untuk mengetahui validitas kuesioner dilakukan dengan mem-bandingkan nila $r$ tabel dengan $r$ hitung, bila $r$ tabel $>\mathrm{r}$ hitung maka pertanyaan dikatakan valid. Reliabilitas ialah indek yang menunjukkan sejauh mana suatu alat ukur dapat dipercaya atau dapat diandalkan. Hal ini berarti menunjukkan sejauh mana hasil pengukuran itu tetap konsisten atau tetap ajeg (asas) bila dilakukan pengukuran dua kali atau lebih terhadap gejala yang sama dengan menggunakan alat ukur yang sama.

Penelitian menggunakan analisis univariat untuk mendeskripsikan masing- masing variabel yang diteliti. Di mana secara menyeluruh data yang sejenis atau mendekati digabungkan yang kemudian dibuat tabel distribusi frekuensi menggunakan komputerisasi. Penelitian ini menggunakan pengujian kolerasi untuk mengetahui hubungan antar variabel dependen dengan variabel independen. Pembuktiannya menggunakan metode Chi Square, metode ini dipilih karena dua variabel merupakan variabel kategori.Prinsip pengujian Chi Square ini ialah dengan membandingkan frekuensi terjadi (observasi) dengan frekuensi harapan (espektasi). Pembuktian uji Chi Square menggunakan 
komputerisasi. Peneliti menggunakan uji Chi Square dengan tingkat kepercayaan 95\% atau tingkat kemaknaan sebesar 5\%.Bila nilai $p$-value $\leq 0.05$ berarti hasil perhitungan statistik bermakna serta apabila $p$-value $>0.05$ berarti hasil perhitungan statistik tidak bermakna. Interprestasi data disajikan dalam bentuk narasi sehingga memudahkan pemahaman terhadap hasil penelitian, yaitu diungkapkan bahwa berdasarkan teori yang ada dapat dilihat hubungan persepsi ibu, dukungan suami serta dukungan tempat kerja dengan pemberian asi ekslusif pada ibu bekerja di CV. Tri Corp Kabupaten Bogor.

\section{Hasil}

Tabel 1. Distribusi Frekuensi Pemberian ASI Ekslusif, Persepsi Ibu, Dukungan Suami, Dukungan Tempat Kerja Pada Ibu bekerja di CV. Tri Corp Kabupaten Bogor

\begin{tabular}{lcc}
\hline \multicolumn{1}{c}{ Variabel } & $\begin{array}{c}\text { Frekuensi } \\
(\mathbf{f})\end{array}$ & $\begin{array}{c}\text { Presentase } \\
(\mathbf{\%})\end{array}$ \\
\hline Pemberian ASI Ekslusif & & \\
\hline Tidak ASI Eklusif & 22 & 52,4 \\
\hline ASI Ekslusif & 20 & 47,6 \\
\hline Persepsi Ibu & & 52,4 \\
\hline Kurang Baik & 22 & 47,6 \\
\hline Baik & 20 & \\
\hline Dukungan Suami & & 54,8 \\
\hline Kurang Baik & 23 & 45,2 \\
\hline Baik & 19 & 42,9 \\
\hline Dukungan Tempat Kerja & & 57,1 \\
\hline Kurang Baik & 18 & \\
\hline Baik & 24 & \\
\hline
\end{tabular}

Sumber: Data Primer, 2019

Tabel 2. Hubungan Persepsi Ibu, Dukungan Suami dan Dukungan Tempat Kerja dengan Pemberian ASI Ekslusif Pada Ibu Bekerja di CV. Tri Corp Kabupaten Bogor

\begin{tabular}{|c|c|c|c|c|c|c|c|c|}
\hline \multirow{2}{*}{ Variabel } & \multicolumn{2}{|c|}{$\begin{array}{l}\text { Tidak ASI } \\
\text { Eksklusif }\end{array}$} & \multicolumn{2}{|c|}{ ASI Eksklusif } & \multicolumn{2}{|c|}{ Total } & \multirow{2}{*}{ p-Value } & \multirow{2}{*}{ OR } \\
\hline & f & $\%$ & f & $\%$ & f & $\%$ & & \\
\hline \multicolumn{9}{|l|}{ Persepsi } \\
\hline Kurang baik & 16 & 72,7 & 6 & 27,3 & 22 & 100 & & \\
\hline Baik & 6 & 30 & 14 & 70 & 20 & 100 & 0,014 & 6,222 \\
\hline Jumlah & 22 & 52,4 & 20 & 47,6 & 42 & 100 & & \\
\hline \multicolumn{9}{|c|}{ Dukungan Suami } \\
\hline Kurang baik & 16 & 69,6 & 7 & 30,4 & 23 & 100 & & \\
\hline Baik & 6 & 31,6 & 13 & 68,4 & 19 & 100 & 0,032 & 4,952 \\
\hline Jumlah & 22 & 52,4 & 20 & 47,6 & 42 & 100 & & \\
\hline \multicolumn{9}{|l|}{$\begin{array}{l}\text { Dukungan } \\
\text { Tempat Kerja }\end{array}$} \\
\hline Kurang baik & 14 & 77,8 & 4 & 22,2 & 18 & 100 & & \\
\hline Baik & 8 & 33,3 & 16 & 66,7 & 24 & 100 & 0,011 & 7,000 \\
\hline Jumlah & 22 & 52,4 & 20 & 47,6 & 42 & 100 & & \\
\hline
\end{tabular}

Sumber: Data Primer, 2019 


\section{SIMFISIS Jurnal Kebidanan Indonesia}

Volume 01, Nomor 01, Agustus 2021

Berdasarkan tabel 1 diketahui pemberian ASI Ekslusif Pada Ibu bekerja di CV. Tri Corp Kabupaten Bogor Tahun 2019 sebanyak 22 orang (53,4\%) tidak ASI eksklusif dan 20 orang $(47,6 \%)$ ASI Ekslusif. Persepsi Ibu tentang pemberian ASI Ekslusif di CV. Tri Corp Kabupaten Bogor Tahun 2019 sebanyak 22 orang $(53,4 \%)$ kurang baik dan 20 orang $(47,6 \%)$ baik. Dukungan suami tentang pemberian ASI Ekslusif di CV. Tri Corp Kabupaten Bogor Tahun 2019 sebanyak 23 orang (54,8\%) kurang baik dan 19 orang $(45,2 \%)$ baik. Dukungan tempat kerja tentang pemberian ASI Ekslusif sebanyak 18 orang $(42,9 \%)$ kurang baik dan 24 orang $(57,1 \%)$ baik.

Berdasarkan tabel 2 didapatkan hasil hubungan antara persepsi ibu dengan Pemberian ASI Ekslusif Pada Ibu bekerja diperoleh bahwa ada sebanyak 16 dari 22 responden (72,7\%) persepsi kurang baik dengan tidak ASI eksklusif dan sebanyak 14 dari 20 responden $(70 \%)$ persepsi baik dengan ASI eksklusif. Hasil uji statistik didapatkan nilai $\mathrm{P}$ value $=0,014$ berarti $\mathrm{p}$ value $<\alpha(0,050)$ sehingga dapat disimpulkan ada hubungan antara persepsi ibu dengan Pemberian ASI Ekslusif Pada Ibu bekerja di CV. Tri Corp Kabupaten Bogor Tahun 2019.

Dari hasil analisis nilai OR 6,222 artinya responden yang persepsi kurang baik berpeluang 6,2 kali tidak memberikan ASI eksklusif dibandingkan persepsi baik. Didapatkan hasil hubungan antara dukungan suami ibu dengan Pemberian ASI Ekslusif Pada Ibu bekerja diperoleh bahwa ada sebanyak 16 dari 23 responden (69.9\%) dukungan suami kurang baik dengan tidak ASI eksklusif dan sebanyak 13 dari 19 responden $(68,4 \%)$ dukungan suami baik dengan ASI eksklusif. Hasil uji statistik didapatkan nilai $\mathrm{P}$ value $=0,032$ berarti $\mathrm{p}$ value $<\alpha(0,050)$ sehingga dapat disimpulkan ada hubungan antara dukungan suami ibu dengan Pemberian ASI Ekslusif Pada Ibu bekerja di CV. Tri Corp Kabupaten Bogor Tahun 2019. Dari hasil analisis nilai OR 4,952 artinya responden yang dukungan suami kurang baik berpeluang 4,9 kali tidak memberikan ASI eksklusif dibandingkan dukungan suami baik. Didapatkan hasil hubungan antara dukungan tempat kerja ibu dengan Pemberian ASI Ekslusif Pada Ibu bekerja diperoleh bahwa ada sebanyak 14 dari 18 responden $(77,8 \%)$ dukungan tempat kerja kurang baik dengan tidak ASI eksklusif dan sebanyak 16 dari 24 responden (66,7\%) dukungan tempat kerja baik dengan ASI eksklusif. Hasil uji statistik didapatkan nilai $\mathrm{P}$ value $=0,011$ berarti $\mathrm{p}$ value $<\alpha(0,050)$ sehingga dapat disimpulkan ada hubungan antara dukungan tempat kerja ibu dengan Pemberian ASI Ekslusif Pada Ibu bekerja di CV. Tri Corp Kabupaten Bogor Tahun 2019. Dari hasil analisis nilai OR 7,000 artinya responden yang dukungan tempat kerja kurang baik berpeluang 7 kali tidak memberikan ASI eksklusif dibandingkan dukungan tempat kerja baik.

\section{Pembahasan}

\section{Hubungan Antara Persepsi Ibu dengan Pemberian ASI Ekslusif Pada Ibu Bekerja di CV. Tri Corp Kabupaten Bogor}

Berdasarkan hasil penelitian diketahui hasil hubungan antara persepsi ibu dengan Pemberian ASI Ekslusif Pada Ibu bekerja di CV. Tri Corp Kabupaten Bogor diperoleh bahwa ada sebanyak 16 dari 22 responden $(72,7 \%)$ persepsi kurang baik dengan tidak ASI eksklusif dan sebanyak 14 dari 20 responden (70\%) persepsi baik dengan ASI eksklusif. Hasil uji statistik didapatkan nilai $\mathrm{P}$ value $=0,014$ berarti $\mathrm{p}$ value $<\alpha(0,05)$ sehingga dapat disimpulkan ada hubungan antara persepsi ibu dengan Pemberian ASI Ekslusif Pada Ibu bekerja di CV. Tri Corp Kabupaten Bogor Tahun 2019. Dari hasil analisis nilai OR 6,222 artinya responden yang persepsi kurang baik berpeluang 6,2 kali tidak memberikan ASI eksklusif dibandingkan persepsi baik. 


\section{SIMFISIS Jurnal Kebidanan Indonesia}

Volume 01, Nomor 01, Agustus 2021

Sejalan dengan penelitian penelitian oleh Tasnim, et al, menyebutkan bahwa $21,2 \%$ responden tidak memberikan ASI Eksklusif karena faktor kurangnya pengetahuan. ${ }^{15}$ Persepsi merupakan penerimaan (receiving) dari suatu peristiwa yang mempunyai konsekuensi terhadap orang atau kelompok. Persepsi ialah proses dari suatu pengorganisasian, interprestasi pada suatu rangsangan yang dapat diterima oleh seseorang sehingga menjadi ssuatu yang berarti serta merupakan suatu aktivitas yang integrated diri individunya. Persepsi ialah suatu proses yang dapat dipergunakan seseorang untuk mengelola serta mentafsirkan dari pengindraannya untuk dapat memberikan makna kepada lingkungannya. Meski demikian apa yang di persepsikan seseorang dapat berbeda dari kenyataan yang objektif. Persepsi ialah sesuatu mengenai kualitas, barang, ataupun hubungannya serta perbedaan diantara hal tersebut melalui tahapan proses mengetahui, mengamati, maupun mengartikan setelah mendapatkan rangsang. Oleh karena itu persepsi juga dapat diartikan sebagai suatu proses yang diterima dari rangsang melalui pengindraan dengan perhatian sehingga seseorang mampu mengartikan, mengetahui serta menghayati tentang hal-hal yang dapat diamati, secara yang ada diluar ataupun yang ada dalam diri seseorang. ${ }^{16}$

Persepsi ialah suatu proses yang dapat dipergunakan seseorang untuk mengelola serta mentafsirkan dari pengindraannya untuk dapat memberikan makna kepada lingkungannya. Meski demikian apa yang di persepsikan seseorang dapat berbeda dari kenyataan yang objektif. Sedangkan Maramis mengemukakan persepsi ialah sesuatu mengenai kualitas, barang, ataupun hubungannya serta perbedaan diantara hal tersebut melalui tahapan proses mengetahui, mengamati, maupun mengartikan setelah mendapatkan rangsang. Oleh karena itu persepsi juga dapat diartikan sebagai suatu proses yang diterima dari rangsang melalui pengindraan dengan perhatian sehingga seseorang mampu mengartikan, mengetahui serta menghayati tentang hal-hal yang dapat diamati, secara yang ada diluar ataupun yang ada dalam diri seseorang. ${ }^{16}$

Proses terbentuknya suatu persepsi didasari pada beberapa tahap, diantaranya Adanya persepsi dapat diawali sewaktu seseorang dihadapkan dengan suatu stimulus ataupun rangsangan yang ada dari lingkungan. Pada proses registrasi suatu gejala yang dapat dilihat dari mekanisme fisik yang dapat berpengaruh pada alat indera yang dimiliki. Interpretasi ialah suatu aspek kognitif daripada persepsi yaitu merupakan proses dalam memberikan sebuah arti pada stimulus yang diterima oleh individu. ${ }^{17}$

Sasaran pada persepsi yaitu berupa orang, benda maupun peristiwa yangmana sifat-sifat tersebut dari sasaran persepsi akan mempengaruhi orang yang melihatnya. Jika individu melihat sesuatu serta berupaya memberikan gambaran tentang apa yang individu dilihat. Hal tersebut yang dapat berpengaruh yaitu karakteristik individual sikap, motif, kepentingan, minat, pengalaman, serta pengharapan. Sasaran pada persepsi yaitu berupa orang, benda maupun peristiwa yangmana sifat-sifat tersebut dari sasaran persepsi akan mempengaruhi orang yang melihatnya. Persepsi dapat dilihat dengan cara kontekstual yang artinya pada situasi seperti apa persepsi dapat timbul serta mendapatkan suatu perhatian yang dapat memiliki hubungan timbal baliknya. Situasi ialah faktor yang turut dapat berperan pada tumbuhnya persepsi individu, contohnya seorang anak dapat menunjukkan suatu pola perilaku tertentu apabila dihadapkan pada orang tua, seperti sopan, tertib, dan lainnya. Persepsi merupakan suatu pandangan keadaan dan pola pikir tentang berat atau tidaknya ibu dalam memberikan ASI kepada anak usia 0-6 bulan secara eksklusif. ${ }^{18}$

Menurut asumsi peneliti bahwa pada ibu pekerja banyak yang beranggapan bahwa dengan memberikan susu formula anak sudah cukup dan baik dari segi nutrisi serta dengan memberikan susu formula ibu tidak terganggu dengan pekerjaannya. Ada juga dengan persepsi yang salah bagi ibu tentang menyusui yang mana jika menyusui dapat membuat daya tariknya pada seorang ibu sebagai wanita 


\section{SIMFISIS Jurnal Kebidanan Indonesia}

Volume 01, Nomor 01, Agustus 2021

menurun serta dapat penghambat ASI eksklusif. Alasan lainnya yang rendahnya pemberian ASI Eksklusif ialah kurangnya pengetahuan bagi manajemen laktasi dan sikap terhadap manejemen laktasi.

\section{Hubungan Antara Dukungan Suami dengan Pemberian ASI Ekslusif Pada Ibu Bekerja di CV. Tri Corp Kabupaten Bogor}

Berdasarkan hasil penelitian diketahui hasil hubungan antara dukungan suami ibu dengan Pemberian ASI Ekslusif Pada Ibu bekerja di CV. Tri Corp Kabupaten Bogor Tahun 2019 diperoleh bahwa ada sebanyak 16 dari 23 responden (69.9\%) dukungan suami kurang baik dengan tidak ASI eksklusif dan sebanyak 13 dari 19 responden $(68,4 \%)$ dukungan suami baik dengan ASI eksklusif. Hasil uji statistik didapatkan nilai $\mathrm{P}$ value $=0,032$ berarti $\mathrm{p}$ value $<\alpha(0,05)$ sehingga dapat disimpulkan ada hubungan antara dukungan suami ibu dengan Pemberian ASI Ekslusif Pada Ibu bekerja di CV. Tri Corp Kabupaten Bogor Tahun 2019. Dari hasil analisis nilai OR 4,952 artinya responden yang dukungan suami kurang baik berpeluang 4,9 kali tidak memberikan ASI eksklusif dibandingkan dukungan suami baik. Sejalan dengan hasil penelitian Farha menjelaskan bahwa hubungan dukungan suami dengan kemauan ibu memberikan ASI eksklusif di Puskesmas Tuminting tahun 2014. Hasil uji statistik menggunakan uji chi square didapatkan nilai $p=0,001$. Ini berarti bahwa nilai $p<\alpha(0,05)$. Dengan demikian dapat disimpulkan bahwa terdapat hubungan antara dukungan suami dengan kemauan ibu memberikan ASI eksklusif. ${ }^{10}$

Dukungan suami ialah sikap, tindakan dan penerimaan suami terhadap anggotanya. Anggota suami dipandang sebagai bagian yang tidak terpisahkan dalam lingkungan suami. Anggota suami memandang bahwa orang yang bersifat mendukung selalu siap memberikan pertolongan dan bantuan jika diperlukan. Dukungan suami sebagai pengawas dan pemberi semangat kepada penderita mempunyai peran yang sangat besar dalam peningkatan pengobatan penderita. Berbagai pengetahuan yang benar tentang Persalinan perlu diketahui oleh para penderita dan suaminya serta masyarakat luas pada umumnya. Penderita dan suaminya tentu perlu tahu seluk beluk penyakit ini agar kesembuhan dapat dicapai. Dalam hal penderita persalinan, dukungan suami memiliki peranan yang besar dalam hal memberikan dorongan berobat kepada pasien. Suami ialah orang yang pertama yang tahu tentang kondisi sebenarnya dari penderita Persalinan dan orang yang paling dekat serta berkomunikasi setiap hari dengan penderita. ${ }^{19}$

Dukungan suami sangat berpengaruh terhadap keberhasilan pemberian ASI esklusif. Terdapat dua kategori yang berpengaruh terhadap keberhasilan pemberian ASI ekslusif, salah satu diantaranya ialah pengaruh sosial primer yaitu dukungan orang-orang terdekat. Dukungan suami dapat meningkatkan rasa percaya diri pada ibu menyusui. Produksi ASI juga meningkat karena perasaan nyaman yang dialami oleh ibu yang mendapat dukungan suami. Dalam pengawasan pengobatan, bidanharus mengikutsertakan suami sebagai pengawas pengobatan agar penderita dapat berobat secara kontinyu. Dukungan suami sebagai pengawas dan pemberi semangat kepada penderita mempunyai peran yang sangat besar dalam peningkatan pengobatan penderita. Berbagai pengetahuan yang benar tentang Persalinan perlu diketahui oleh para penderita dan suaminya serta masyarakat luas pada umumnya. Penderita dan suaminya tentu perlu tahu seluk beluk penyakit ini agar kesembuhan dapat dicapai. Dalam hal penderita persalinan, dukungan suami memiliki peranan yang besar dalam hal memberikan dorongan berobat kepada pasien. Suami ialah orang yang pertama yang tahu tentang kondisi sebenarnya dari penderita Persalinan dan orang yang paling dekat serta berkomunikasi setiap hari dengan penderita. Suami merupakan tempat yang aman serta damai agar dapat istirahat serta 


\section{SIMFISIS Jurnal Kebidanan Indonesia}

Volume 01, Nomor 01, Agustus 2021

pemulihan untuk dapat membantu penguasaan terhadap emosi. Aspek ini dari dukungan emosional diantaranya dalam bentuk afeksi, adanya kepercayaan, perhatian, mendengarkan dan didengarkan.20 Perasaan tenang, tentrak dan nyaman yang dirasakan oleh ibu menyusui dapat meningkatkan produksi hormone oksitosin. Ibu menyusui yang mendapatkan dukungan dari anggota keluarga, terutama suami atau pasangan dan kakek-nenek, berpengaruh positif terhadap kepercayaan diri ibu menyusui. Anggota keluarga harus mendukung ibu dan membantu ibu dalam hal pemberian ASI sehingga ibu merasa mampu dan didukung untuk menyusui. ${ }^{9}$

Suami yang mempunyai fungsi pemberi informasi serta menjelaskan tentang bagaimana memberikan saran, sugesti serta informasi yang akan dipergunakan pada suatu masalah. Suami yang mempunyai fungsi pemberi informasi serta menjelaskan tentang bagaimana memberikan saran, sugesti serta informasi yang akan dipergunakan pada suatu masalah. Suami yang mempunyai fungsi pemberi informasi serta menjelaskan tentang bagaimana memberikan saran, sugesti serta informasi yang akan dipergunakan pada suatu masalah. ${ }^{21}$

Menurut asumsi peneliti bahwa dukungan suami dapat meningkatkan rasa percaya diri pada ibu menyusui. dukungan yang baik dari suami yaitu suami yang mempunyai fungsi pemberi informasi serta menjelaskan tentang ASI eksklusif dan Suami dapat memberikan pertolongan praktis serta konkrit dalam proses menyusui istri seperti pembelian pompa ASI dan memberikan makanan yang bergizi.

\section{Hubungan Antara Dukungan Tempat Kerja Pemberian ASI Ekslusif Pada Ibu Bekerja di CV. Tri Corp Kabupaten Bogor}

Berdasarkan hasil penelitian diketahui hasil hubungan antara dukungan tempat kerja ibu dengan Pemberian ASI Ekslusif Pada Ibu bekerja di CV. Tri Corp Kabupaten Bogor Tahun 2019 diperoleh bahwa ada sebanyak 14 dari 18 responden $(77,8 \%)$ dukungan tempat kerja kurang baik dengan tidak ASI eksklusif dan sebanyak 16 dari 24 responden $(66,7 \%)$ dukungan tempat kerja baik dengan ASI eksklusif. Hasil uji statistik didapatkan nilai $\mathrm{P}$ value $=0,011$ berarti $\mathrm{p}$ value $<\alpha(0,05)$ sehingga dapat disimpulkan ada hubungan antara dukungan tempat kerja ibu dengan Pemberian ASI Ekslusif Pada Ibu bekerja di CV. Tri Corp Kabupaten Bogor Tahun 2019. Dari hasil analisis nilai OR 7,000 artinya responden yang dukungan tempat kerja kurang baik berpeluang 7 kali tidak memberikan ASI eksklusif dibandingkan dukungan tempat kerja baik.

Sejalan dengan penelitian Rizki bahwa Tujuan penelitian ini ialah untuk mengetahui hubungan sikap, dukungan sarana, atasan dan suami terhadap keberhasilan ibu menyusui pada ibu bekerja. Hasil penelitian didapatkan sikap ibu bekerja, dukungan sarana, atasan dan suami berpengaruh terhadap keberhasilan pemberian ASI eksklusif oleh ibu bekerja $(p<0,05)$. Kesimpulannya ialah ada hubungan yang signifikan antara keberhasilan pemberian asi eksklusif dengan sikap ibu, dukungan sarana, atasan dan suami. ${ }^{11}$ Lingkungan kerja yang ada di dalam perusahaan sangat penting agar dapat diperhatikan oleh manajemen. Lingkungan kerja ialah suasana yang mana karyawan dapat melakukan aktivitasnya setiap harinya di tempat kerja. Lingkungan kerja yang kondusif dapat memberikan rasa aman serta nyaman untuk memungkinkan karyawan dapat bekerja secara optimal. Apabila karyawan menyukai lingkungan kerja ditempat dia bekerja, maka karyawan tersebut dapat merasa nyaman dikeberadaannya dalam melakukan aktivitas dengan efektif. ${ }^{22}$

Dalam kaitanya dengan penyediaan fasilitas khusus menyusui dan/atau memerah air susu ibu menurut Peraturan Menteri Kesehatan Republik Indonesia Nomor 15 Tahun 2013 bahwa untuk melaksanakan ketentuan Pasal 30 ayat (4) Peraturan Pemerintah Nomor 33 tahun 2012 tentang Pemberian Air Susu Ibu Eksklusif, perlu menetapkan Peraturan Menteri Kesehatan tentang Tata Cara 


\section{SIMFISIS Jurnal Kebidanan Indonesia}

Volume 01, Nomor 01, Agustus 2021

Penyediaan Fasilitas Khusus Menyusui dan/atau Memerah Air Susu Ibu. ${ }^{23}$ Dukungan kepada ibu menjadi satu faktor yang juga mempengaruhi ibu memberikan ASI eksklusif. Keadaan tenang ini didapat oleh ibu jika adanya dukungan- dukungan dari lingkungan sekitar ibu untuk memberikan ASI kepada bayinya. Karena itu, ibu memerlukan dukungan yang kuat agar dapat memberikan ASI eksklusif. Menyusui dapat dilakukan baik secara langsung maupun tidak langsung. Menyusui secara tidak langsung dilakukan dengan memberikan ASI perah dalam kondisi segar maupun tersimpan. Beberapa perusahaan ada yang sudah menyediakan ruang laktasi dengan segala perlengkapannya berupa lemari pendingin, apron, air hangat, bantal menyusui. Namun, beberapa diantaranya ada yang membatasi hingga saat ini masih banyak pekerja perempuan yang tidak dapat melaksanakan haknya untuk memberikan ASI selama bekerja. ${ }^{24}$

Persyaratan kesehatan Ruang ASI sebagaimana dimaksud dalam Pasal 9ayat (2) paling sedikit meliputi: tersedianya ruangan khusus dengan ukuran minimal $3 \times 4 \mathrm{~m} 2$ dan/atau disesuaikan dengan jumlah pekerja perempuan yang sedang menyusui, ada pintu yang dapat dikunci, yang mudah dibuka/ditutup, .lantai keramik/semen/karpet; d.memiliki ventilasi sertasirkulasi udara yang cukup, bebas potensi bahaya di tempat kerja termasuk bebas polusi; f.lingkungan cukup tenang jauh dari kebisingan, penerangan dalam ruangan cukup sertatidak menyilaukan sertah.tersedia wastafel dengan air mengalir untuk cuci tangan sertamencuci peralatan dll. Dukungan Lingkungan Kerja Tentang Program ASI Ekslusif diantaranya ialah Perusahaan menyiapkan Sarana Umum pendung program ASI Eksklusif. Menyediakan fasilitas menyusui atau pemerah ASI. Membnerikan kebijakan untuk melakukan pemerahan susu di waktu jam kerja. Pembuatan peraturan internal perusahaan sebagai dukungan keberhasilan ASI Eksklusif. Adanya Tenaga Terlatih tentang kesehatan terutama tentang $\mathrm{ASI}^{23}$

Menurut asumsi peneliti bahwa Lingkungan kerja merupakan lingkungan sosial yang berperangaruh terhadap keberhasilan pemberian ASI eksklusif bagi ibu bekerja. Lingkungan kerja dapat memberikan dukungan dalam bentuk dukungan dari rekan kerja, supervisor, tersedianya tempat menyusui atau memerah ASI dan dukungan penuh dari pimpinan atau pemilik perusahaan.

\section{Kesimpulan}

Berdasarkan hasil penelitian yang penulis lakukan tentang hubungan persepsi ibu, dukungan suami dan dukungan tempat kerja dengan pemberian ASI Ekslusif Pada Ibu bekerja di CV. Tri Corp Kabupaten Bogor Tahun 2019, sesuai dengan pelaksanaan dapat ditarik kesimpulan sebagai berikut. Ada hubungan antara persepsi ibu dengan Pemberian ASI Ekslusif Pada Ibu bekerja di CV. Tri Corp Kabupaten Bogor Tahun 2019. Ada hubungan antara persepsi ibu dengan Pemberian ASI Ekslusif Pada Ibu bekerja di CV. Tri Corp Kabupaten Bogor Tahun 2019. Ada hubungan antara persepsi ibu dengan Pemberian ASI Ekslusif Pada Ibu bekerja di CV. Tri Corp Kabupaten Bogor Tahun 2019.

Saran bagi tempat penelitian. Membuat ruang ASI dan meningkatkan fasilitas Ruang ASI agar dapat digunakan dengan nyaman bagi ibu menyusui. Menyediakan tenaga kesehatan untuk melakukan konseling bagi ibu hamil dan menyusui. Perusahaan melakukan promosi kesehatan dengan pemasangan poster tentang pentingnya pemeberian ASI ekskusif.

\section{Konflik Kepentingan}

\section{Ucapan Terima Kasih}




\section{SIMFISIS Jurnal Kebidanan Indonesia}

\section{Pendanaan}

$-$

\section{References}

1. Wulandari, S \& Handayani S. Asuhan Kebidanan Ibu Masa Nifas. Yogyakarta. Publishing; 2011.

2. World Health Organization. Maternal mortality in 1990-2015. Russ Fed. Published online 2015.

3. Profil Kesehatan 2017. Data Profile Kesehatan Indonesia 2017. Ministry Health Indonesia. Published online 2012. doi:10.1002/qj

4. IDAI. Pemberian Makanan Pendamping Air Susu Ibu (MPASI). UKK Nutr dan Penyakit Metab IDAI. Published online 2018.

5. World Health Organization. Noncommunicable Diseases Progress Monitor 2015. Who. Published online 2015.

6. Pratiwi ST. Mikrobiologi Farmasi; 2008.

7. Abdullah GI, Ayubi D. Determinan Perilaku Pemberian Air Susu Ibu Eksklusif pada Ibu Pekerja. Kesmas Natl Public Heal J. Published online 2013. doi:10.21109/kesmas.v7i7.27

8. Helda H. Kebijakan Peningkatan Pemberian ASI Eksklusif. Kesmas Natl Public Heal J. Published online 2009. doi:10.21109/kesmas.v3i5.209

9. Public F, Reeves CC, Close FT, Simmons MC, Hollis AL. Social Support Indicators That Influence Breastfeeding Decisions in Mothers of North Florida.; 2006.

10. Abidjulu F, Hutagaol E, Kundre R. Hubungan Dukungan Suami Dengan Kemauan Ibu Memberikan Asi Eksklusif Di Puskesmas Tuminting Kecamatan Tuminting. J Keperawatan UNSRAT. Published online 2015.

11. Amalia R, Rizki LK. Faktor Faktor yang Mempengaruhi Keberhasilan Ibu Bekerja dalam Pemberian ASI Eksklusif. Mandala Heal a Sci J. Published online 2018.

12. Aziz Alimul Hidayat. Metode Penelitian Kebidanan Dan Teknik Analisis Data.; 2014.

13. Notoatmodjo. Metodologi Penelitian Kesehatan Cetakan Kedua. Rineka Cipta. Published online 2012.

14. Sugiyono. Metode Penelitian Kuantitatif,Kualitatif dan R\&D. Ke-26. Published online 2018.

15. Tasnim S, Akhtar S, Haque FM. Nutritional Status and Breast Feeding Practice among Mothers Attending Lactation Management Centre. Pediatr Res Int J. Published online 2014. doi:10.5171/2014.790373

16. Aziz MF, Andrijono, Saifuddin AB. Buku Acuan Nasional Onkologi Ginekologi. Jakarta Yayasan Bina Pustaka Sarwono Prawirohardjo. Published online 2010.

17. Thoha M. Some Applic.; 2006.

18. Notoatmodjo S. Promosi Kesehatan, Teori \& Aplikasi, ed. revisi 2010. Jakarta: Rineka Cipta. Published online 2010. doi:10.1108/JMTM-03-2018-0075

19. Friedman, M. M., Bowden, V. R., \& JonesEG. Buku Ajar Keoerawatan Keluarga (Riset, teori, dan praktik) Edisi 5. In: 5. ; 2014.

20. Nesbitt SA, Campbell KA, Jack SM, Robinson H, Piehl K, Bogdan JC. Canadian adolescent mothers' perceptions of influences on breastfeeding decisions: A qualitative descriptive study. BMC Pregnancy Childbirth. Published online 2012. doi:10.1186/1471- 2393-12-149

21. Friedman. Buku Ajar Keperawatan Keluarga Riset, Teori Dan Praktik.; 2015.

22. Nitisemito \& AS. Manajemen Personalia. In: Bogor: Ghalia Indonesia. ; 2001.

23. Kemenkes RI. Peraturan Menteri Kesehatan Republik Indonesia Nomor 15 Tahun 2013 Tata Cara Penyediaan Fasilitas Khusus Menyusui dan/atau Memerah Air Susu Ibu. Peratur Menteri Kesehat. Published online 2013.

24. Basrowi R. Pemberian ASI eksklusif pada perempuan pekerja sektor formal. Published online 2012. 